\title{
Wetland Management for Amphibians in the Willamette Valley
}

\section{Introduction}

In the past two decades, scientists around the world have increasingly noted losses of amphibian populations ${ }^{1}$. Many of these declines have occurred in protected areas like national parks, where the causes mostly remain mysterious. However, in multipleuse landscapes, resource managers frequently face more obvious conservation problems and must make decisions that will affect amphibians. The purpose of this fact sheet is to present recent findings pertinent to wetland management and amphibians in a multiple-use landscape.

The Willamette Valley lies between the Cascade Range and the Coast Range in western Oregon. It surrounds a $150-\mathrm{km}$ stretch of the Willamette River and has an average width of $30 \mathrm{~km}$ and an average elevation of about 150 m. Characterized by a sub-maritime climate, the valley is predominantly agricultural, but several rapidly growing urban centers exist. The valley's numerous wetlands were created by river flows or for livestock, recreation, or wetland mitigation. Amphibians use a mix of permanent and ephemeral (seasonally inundated) wetlands; the latter tend to fill during fall rains and dry by mid- to late summer.

Five species of native amphibians breed in wetlands of the Willamette Valley (Table 1). A sixth (the Oregon spotted frog) is presumed extinct. Native fish are mostly riverine, but several species arrive with some regularity at wetlands via flooding or connections to riverine habitats: the threespine stickleback (Gasterosteus aculeatus), red-side shiner (Richardsonius balteatus), and sculpin (Cottus spp.).

Table 1. Willamette Valley Amphibians
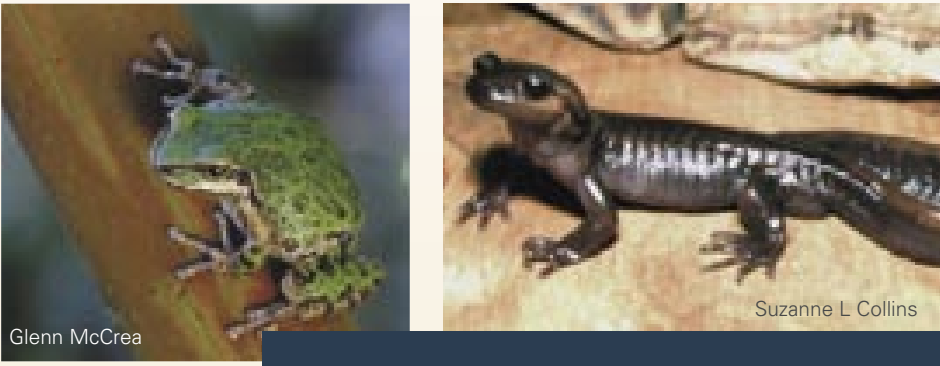

In the past two decades, scientists around the world have increasingly noted losses of amphibian populations.

\begin{tabular}{lccccc}
\hline $\begin{array}{l}\text { Species } \\
\text { Common name }\end{array}$ & Scientific name & Native & Oregon status & Metamorphosis & Breeding \\
\hline Bullfrog & Rana catesbeiana & No & Common & $3-12$ months & June-August \\
Long-toed salamander & Ambystoma macrodactylum & Yes & Common & $3-5$ months & January-February \\
Northwestern salamander & Ambystoma gracile & Yes & Unknown & $5-16$ months & February-April \\
Oregon spotted frog & Rana pretiosa & Yes & Extinct in valley & $3-5$ months & February-March \\
Pacific treefrog & Pseudacris regilla & Yes & Common & $3-5$ months & February-March \\
Red-legged frog & Rana aurora & Yes & Sensitive & $3-5$ months & January-March \\
Rough-skinned newt & Taricha granulosa & Yes & Common & $3-5$ months & February-May
\end{tabular}

Recommendations for Conserving Wetland Amphibians

1. Prevent the introduction and establishment of non-native fish in mitigation wetlands by avoiding sites with connections (seasonal or permanent) to permanent streams or wetlands. ${ }^{6-8,14,15,16}$

2. Conserve and create wetlands with at least $50 \%$ of their surface area having depths between 0.2 and $0.75 \mathrm{~m}$ in the spring ${ }^{6-8,14}$

3. Conserve and create ephemeral and semi-permanent wetlands; they tend to have more emergent vegetation and lack non-native vertebrate species, which benefits native amphibians..$^{6-8,14,16}$ 


\section{Known threats to amphibians}

in the Willamette Valley include habitat loss, habitat alteration, and three non-native taxa: fish, bullfrogs, and crayfish.

\section{Amphibian Habitat and Threats}

Known threats to amphibians in the Willamette Valley include habitat loss, habitat alteration, and three non-native taxa: fish, bullfrogs, and crayfish. Wetland mitigation does not currently replace all ephemeral wetlands that are lost to urban and agricultural development. Emergent wetlands have been reduced by $57 \%$ in the past century, and ephemeral wetlands often are replaced with permanent wetlands..$^{2-5}$ Ephemeral wetlands dry periodically

hallow pond mitigation and reed canarygrass - (Phalaris arundinacea)

A primary goal of mitigation is to establish native vegetation and prevent the establishment of aggressive invaders like reed canarygrass. Because shallow wetlands with variable inundation are prone to invasion by reed canarygrass, many mitigation wetlands have historically been designed with steep banks and deep, open water. Although this construction practice minimizes the area suitable for reed canarygrass, it may negatively affect amphibians. Recent data suggest it may be better for native amphibians to have a shallow pond with reed canarygrass than a deep one without. ${ }^{6}$

\section{Box 2}

B ullfrogs and the decline of the Oregon spotted frog Bullfrogs have invaded much of the western range of the Oregon spotted frog which has been extirpated from $>70 \%$ of its historic range. This highly aquatic native species prefers permanent water habitats with extensive vegetated shallows. Because of its aquatic natural history, the Oregon spotted frog may be more susceptible to bullfrog predation than the closely related red-legged frog, which can coexist with bullfrogs. Field observations confirm that Oregon spotted frogs spend the summer months in ponds, like bullfrogs, whereas red-legged frogs generally leave ponds soon after metamorphosis. Oregon spotted frogs appear to be more aquatic, have less ability to escape from bullfrogs, and have lower survival in the presence of bullfrogs than do red-legged frogs. ${ }^{17}$ Thus, while bullfrogs do not appear to be extirpating most native amphibians in the Pacific Northwest, they may still be detrimental to the Oregon spotted frog and perhaps other members of the native fauna. Their large size and generalist feeding habits necessitate that we not dismiss bullfrogs as a threat. and tend to have large, shallow, emergent areas - a desirable characteristic for some amphibians (Box 1). Whereas most native amphibians in the Willamette Valley can breed in both ephemeral and permanent wetlands, many are associated with wetlands having large shallow areas less than $0.75 \mathrm{~m}$ deep in the spring and emergent vegetation covering at least $50 \%$ of the surface area. ${ }^{6-8}$ Ephemeral wetlands that dry as soon as the spring rains cease in May or June may not hold

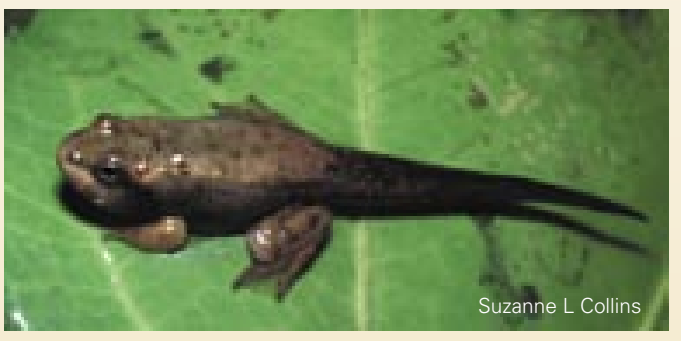
water long enough for amphibians to complete metamorphosis; however, they may be critical for shorebirds and other species that also have suffered from the shift towards more permanent wetlands. ${ }^{9}$

Creating a landscape with a disproportionate amount of deeper, more permanent freshwater habitats favors the invasion of non-native animals. A variety of warm-water fish from the sunfish family (Centrarchidae), especially bluegill (Lepomis macrochirus), pumpkinseed (Lepomis gibbosus), and largemouth bass (Micropterus salmoides), have been widely introduced in the Willamette Valley, along with bullfrogs (Rana catesbeiana). Bullfrogs usually require at least one year to reach metamorphosis and thus need permanent water, but a single summer larval period has been reported. ${ }^{10}$

\section{The Problem with Non-Native Fish and Bullfrogs}

The potential negative effects of non-native fish and bullfrogs on native amphibians have been recognized for decades. ${ }^{11,12}$ However, a large amount of evidence now suggests that most native amphibians in the Pacific Northwest can coexist with bullfrogs in shallow wetlands that have extensive emergent vegetation and lack 


\section{Box 3}

$\mathbf{N}$ on-native fish facilitate bullfrog invasion

Not only do non-native fish appear to be more detrimental to native amphibians than bullfrogs, they also appear to facilitate bullfrog invasion. ${ }^{15}$ Wetlands with high densities of dragonfly nymphs (Aeshnidae) and perhaps other predaceous macroinvertebrates can offer some resistance to bullfrog invasion. In experimental enclosures, predation by dragonfly nymphs reduced survival of bullfrog tadpoles to zero. But when non-native bluegill sunfish were included, the fish ate the dragonfly nymphs and avoided the bullfrog tadpoles (known to be unpalatable to fish), thereby allowing more bullfrogs to survive. Field studies also found that bullfrogs were strongly associated with relatively deep wetlands hosting non-native fish, suggesting that removing fish from some wetlands would not only have direct benefits for native amphibians but might also help manage the bullfrog problem. non-native fish (but see Box 2). ${ }^{6-8,13,14}$ Non-native sunfish pose a greater problem, because red-legged frogs, Pacific treefrogs, and long-toed salamanders appear unable to coexist with them in many habitats. ${ }^{6-8}$

Managing non-native species is difficult. Wetland managers should know that creating wetlands with seasonal or permanent connections to streams or permanent wetlands may result in fish invasion, thereby rendering the wetland unsuitable for most native amphibians. It is imperative that mitigation for the loss of isolated, seasonal wetlands results in new seasonal wetlands with no connections to permanent surface water inhabited by non-native fish.

Efforts to control bullfrogs require extensive commitment of resources and are only feasible at a few wetlands. Periodically draining a wetland during the late summer or early fall is likely the best option but does not prevent bullfrogs from reinvading. We suggest that most effort should focus on managing non-native fish and preventing their spread. Doing so may also help with the bullfrog problem (see Box 3).

It is imperative that mitigation for the loss of isolated, seasonal wetlands results in new seasonal wetlands with no connections to permanent surface water inhabited by non-native fish.
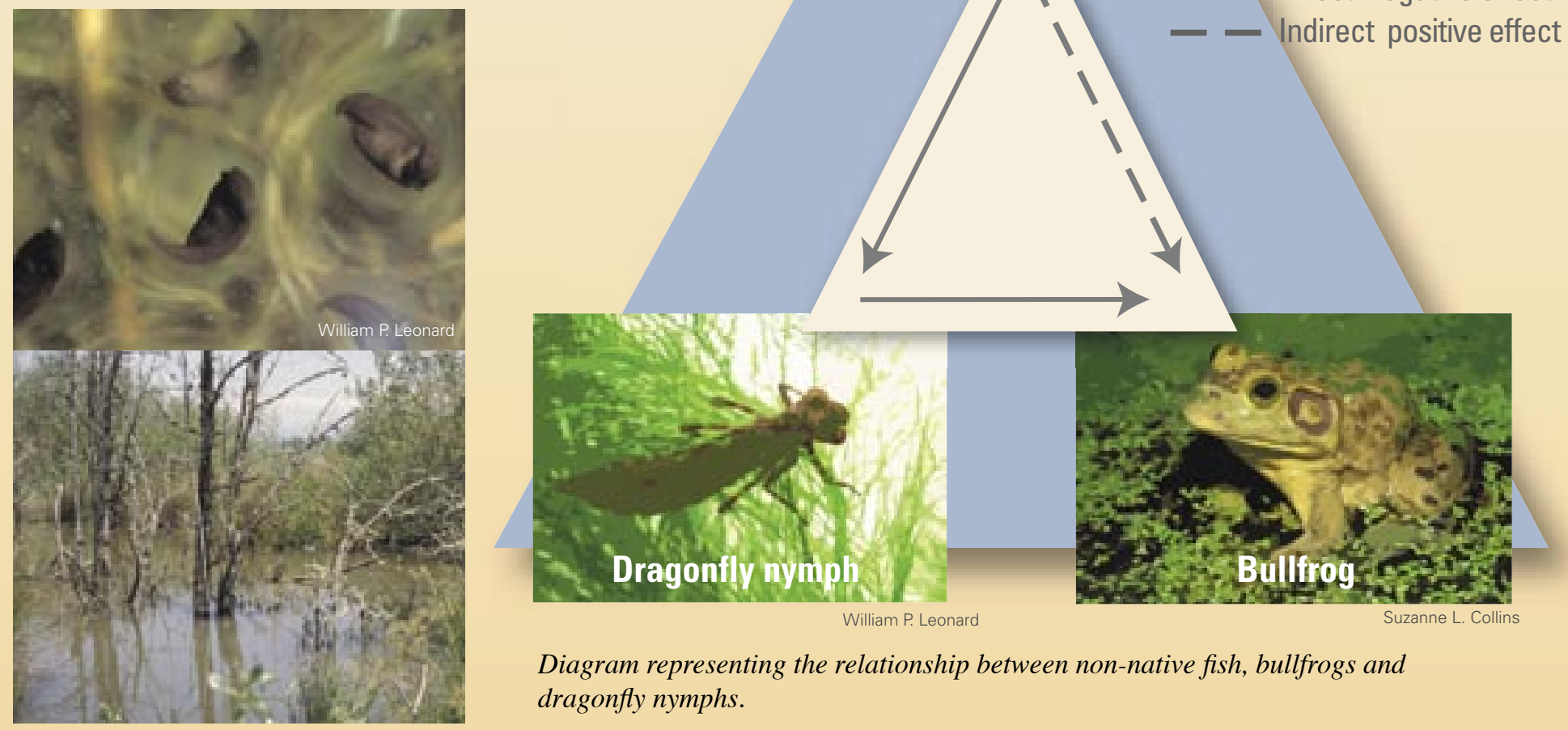

Diagram representing the relationship between non-native fish, bullfrogs and dragonfly nymphs. 


\section{Acknowledgments}

This fact sheet resulted from a research collaboration between the U.S. Environmental Protection Agency (EPA) and the USGS Forest and Rangeland Ecosystem Science Center (FRESC). Primary funding came from EPA's Western Ecology Division and from EPA's Regional Applied Research Program. Additional funding came from the USGS Amphibian Research and Monitoring Initiative and FRESC. We thank J. Baker, S. Heppell, M. Kentula, A. Nebeker, R. Sumner, and Y. Vallette for guidance and helpful discussions throughout this effort. We thank J. Baker, S. Haig, M. Hayes, D. Jarkowsky, W. Leonard, and L. White for suggestions on the content of this fact sheet. Finally, we thank numerous field technicians, laboratory technicians, and land owners who made this study possible.

\section{Literature Cited}

1. Corn, P. S. in Sustainable ecological systems: implementing an ecological approach to land management (eds. Covington, W. \& DeBano, L.) 59-67 (USDA Forest Service. General Technical Report RM-247, Fort Collins, Colorado, USA, 1994).

2. Magee, T. K., Ernst, T. L., Kentula, M. E. \& Dwire, K. A. Floristic comparison of freshwater wetlands in an urbanizing environment. Wetlands $19,517-534$ (1999).

3. Hulse, D. W., Gregory, S. \& Baker, J. (eds.) Willamette River basin: a planning atlas (Oregon State University Press, Corvallis, OR, USA, 2002).

4. Holland, C. C., Honea, J., Gwin, S. E. \& Kentula, M. E. Wetland degradation and loss in the rapidly urbanizing area of Portland, Oregon. Wetlands 15, 336-345 (1995).

5. Kentula, M. E., Sifneos, J. C., Good, J. W., Rylko, M. \& Kunz, K. Trends and patterns in section 404 permitting requiring compensatory mitigation in Oregon and Washington, USA. Environmental Management 16, 109-119 (1992).

6. Pearl, C. A., Adams, M. J., Leuthold, N., \& Bury, R. B. Amphibian occurrence and aquatic invaders in a changing landscape: implications for wetland mitigation in the Willamette Valley, Oregon. Submitted to Wetlands, 29 Jan 2004.

7. Adams, M. J., Bury, R. B. \& Swarts, S. A. Amphibians of the Fort Lewis Military Reservation, Washington: sampling techniques and community patterns. Northwest. Nat. 79, $12-18$ (1998).

8. Adams, M. J. Correlated factors in amphibian decline: exotic species and habitat change in western Washington. J. Wildl. Manag. 63, 1162-1171 (1999).

9. Taft, O. W. \& Haig, S. M. Historical wetlands in Oregon's Willamette Valley: implications for restoration on winter waterbird habitat. Wetlands 23, 51-64 (2003).

10. Heppell, S. S., Wegner, K. A. \& Hackmann, C. Evidence for accelerated metamorphosis in bullfrog (Rana catesbeiana) tadpoles in the Willamette Valley, Oregon. Copeia 2004, to be submitted (2004).

11. Moyle, P. B. Effects of introduced bullfrogs, Rana catesbeiana, on the native frogs of the San Joaquin Valley, California. Copeia 1973, 18-22 (1973).

12. Hayes, M. P. \& Jennings, M. R. Decline of Ranid frog species in western North America: are bullfrogs (Rana catesbeiana) responsible? J. Herpetol. 20, 490509 (1986).

13. Kiesecker, J. M. \& Blaustein, A. R. Effects of introduced bullfrogs and smallmouth bass on microhabitat use, growth, and survival of native red-legged frogs (Rana aurora). Conserv. Biol. 12, 776-787 (1998).

14. Richter, K. O. \& Azous, A. L. Amphibian occurrence and wetland characteristics in the Puget Sound basin. Wetlands 15, 305-312 (1995).

15. Adams, M. J., Pearl, C. A. \& Bury, R. B. Indirect facilitation of an anuran invasion by non-native fishes. Ecology Letters 6, 343-351 (2003).

16. Adams, M. J. Pond permanence and the effects of exotic vertebrates on anurans. Ecological Applications 10, 559-568 (2000).

17. Pearl, C. A., Adams, M. J., Bury, R. B., \& McCreary, B. Asymmetrical effects of introduced bullfrogs (Rana catesbeiana) on native ranid frogs in Oregon. Copeia 2004,11-20 (2004).

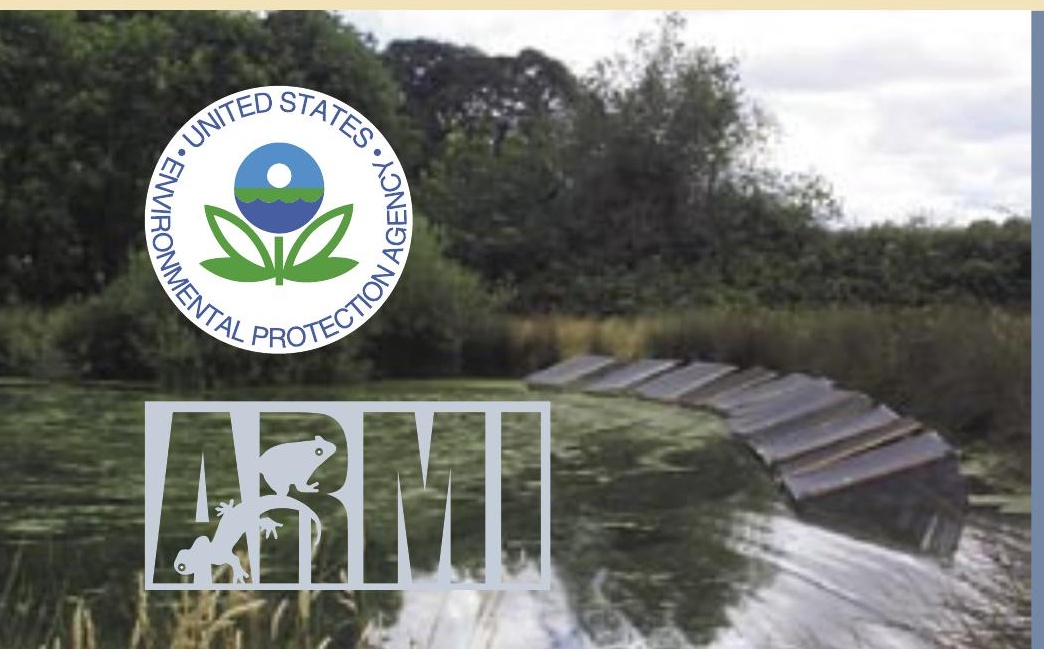

For more information, contact:

Michael J. Adams, Christopher A. Pearl, and R. Bruce Bury

USGS Forest and Rangeland Ecosystem Science Center

3200 SW Jefferson Way

Corvallis, OR 97331

541-758-8857

mjadams@usgs.gov 